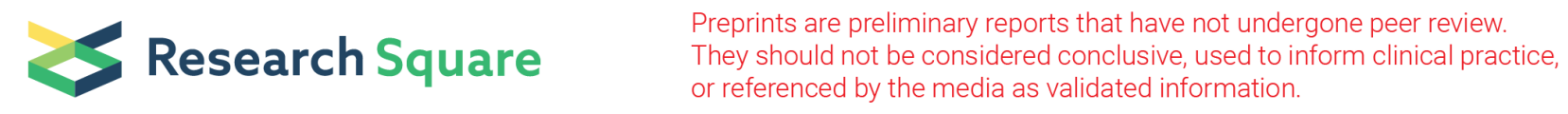

\title{
Title Euthanasia in advanced Dementia; the view of the GPs in the Netherlands on a vignette case along the juridical and ethical dispute. A survey among Dutch general practitioners
}

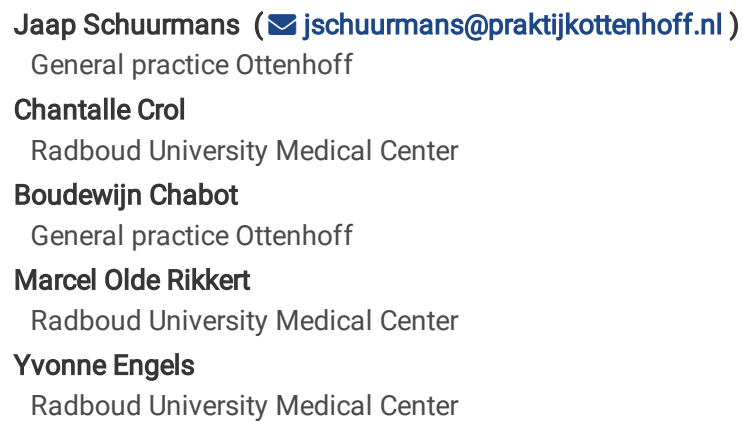




\section{Abstract}

Background In the Netherlands, euthanasia has been regulated by law since 2002 under strict conditions. In the past decade, a growing number of persons with dementia (PWDs) requested for euthanasia, and each year more requests were granted. A euthanasia request from a PWD can have a major impact on a general practitioner (GP), as it requires expertise on medical, communication, legal and ethical aspects, causing uncertainties, dilemmas and doubts. We aimed to get insights in problems and needs GPs experience when confronted with a person with advanced dementia (PWAD) and an advance euthanasia directive (AED.

Methods A postal survey was sent to a random sample of 894 Dutch GPs. As part of this survey, questions were asked about a case vignette about a PWAD who was not able to confirm previous wishes anymore. Quantitative data were analyzed with descriptive statistics.

Results Of the 894 GPs approached, 422 (47.3\%) completed the survey. 176 (41.6\%) of them at least once had had a euthanasia request from a PWD. 178 GPs $(42.2 \%)$ did not agree with the statement that an AED can replace an oral request if communication with the concerned patient has become impossible. About half of the respondents $(209 ; 49.5 \%)$ did not agree that the family can initiate a euthanasia trajectory, 95 GPs $(22.5 \%)$ would accept such a family initiative and $110 \mathrm{GPs}(26.1 \%)$ would under certain conditions.

Discussion In case of PWADs, when confirming previous wishes is not possible anymore, about half of the Dutch GPs would not accept an AED to replace verbal or non-verbal conformation, nor consider performing euthanasia; a minority would. The reported burden and the rise in numbers and complexity of euthanasia requests from PWADs warrants better national professional guidelines and primary care support. Our study shows that due to jurisdiction and changed professional guidelines conflicting views have arisen among Dutch GPs about interpretation of moral, ethical values considering AED and PWADs.

\section{Background}

Death according to personal preference and in a manner that resonates with the person's individuality is increasingly considered as an important element of 'a good death' in modern Western culture.[1] Consequently, an increasing number of countries legalizes euthanasia. Although there are more countries where euthanasia also can be provided to persons with dementia (PWDs), only in the Netherlands an advance euthanasia directive (AED) can replace a verbal request for euthanasia in a later stage of dementia, if all other obligatory criteria are met. [2,3]

BOX1. The requirements of due care in Dutch law as stipulated in the Article 2 of The Termination of Life on Request and Assisted Suicide Act. .

The physician must:

a. Be satisfied that the patient's request is voluntary and well considered.

b. Be satisfied that the patient's suffering is unbearable, with no prospect of improvement.

c. Have informed the patient about his situation and his prognosis.

d. Have come to the conclusion, together with the patient, that there is no reasonable alternative in the patient's situation.

e. Have consulted at least one other, independent physician, who must see the patient and give a written opinion on whether the due care criteria set out in (a) to (d) have been fulfilled.

f. Have exercised due medical care and attention in terminating the patient's life or assisting in his suicide.

The Act stipulates in section 2.2 that a patient aged 16 or over who is decisional competent may draw up an advance directive, setting out a request for euthanasia. If at some point the patient is no longer capable of expressing his will, the physician may accept the advance directive as a request pursuant to section 2 (1)(a) of the Act.1 2 The advance directive thus has the same status as an oral request for euthanasia. Initially, like in other countries, the large majority of euthanasia requests and acts concerned terminal patients with cancer.[4] However, during the last decade, the Dutch number of euthanasia cases in persons with dementia (PWDs) has increased from 25 (of 3136 cases in total) in 2010 to 162 cases (of 6361 in total) in 2019.[5] Indeed, Dutch society, influenced by the growing media and political attention, considers dementia as a debilitating and degrading disease and by many as synonymous with unbearable suffering.[6-8] As most PWDs, especially in the early stages of the disease, live at their own home,[9] particularly GPs are confronted with euthanasia requests of PWDs;[4] a growing number of people in the Netherlands discuss and share an AED with their GP. [10]

Recent studies showed that dealing with AEDs, euthanasia requests and procedures are a burden for GPs; they experience pressure from relatives, have problems with judging mental capacity of PWDs, and the Dutch society's stigmatization of dementia.[11-13 $]^{6}$ Not having the same expectations as and disagreeing with relatives about AEDs, (un)willingness to perform and the timing of euthanasia contributes to this burden.[14-16] (Re)discovering the right balance between the physician's professional responsibility and the patient's and relatives' autonomy in such cases has been recommended.[14]

Until 2015, the Royal Dutch Medical Association (KNMG) directed that, on medical-ethical grounds, it was necessary that the patient verbally or non-verbally confirmed his or her actual death wish when receiving euthanasia, regardless of having an AED. In 2015, the KNMG published its latest guideline, following more liberal possibilities than given by law, in which this was not required as stipulates in section 2.2 (Box 1)[17]. This can be considered a baseline shift, responding to the society expectations to provide maximum juridical space for PWDs.

Recently, a Dutch euthanasia case concerning a woman with advanced dementia was tested against criminal law, to acquire jurisprudence and thereby seeking formal ground for this legal option, which even increased GPs' concerns around euthanasia in PWDs.[18] The Supreme Court in The Hague determined that the woman with advanced dementia in question who was given euthanasia based on her AED without actual confirmation of her request, legally and professionally received sound care in line with the amendment of the law. The case, in which the physician had been accused of murder, was dismissed. $[19,20]$ 
Although this case concerned an elderly care physician working in a nursing home, this first ever euthanasia court case was seen as threatening in primary care across the Netherlands, as GPs typically are confronted with euthanasia requests and AEDs, and carry out $85 \%$ of all euthanasia procedures.[21] Clearly there are professional and legal challenges and ethical concerns GPs face when dealing with euthanasia requests and AEDs from PWDs. We therefore aimed to answer the following research questions: What are the views of Dutch GPs on the obligatory euthanasia criterion of unbearable suffering in PWADs, and on a case vignette about a euthanasia request regarding such a patient with an AED?

\section{Methods}

\section{Study design and participants}

We performed a quantitative survey between January and March 2019. The addresses of a representative sample of 894 Dutch GPs were received from a Dutch institute for healthcare research. GPs, with or without experience with euthanasia requests or procedures in general or with PWDs specifically, were invited to take part, regardless of their opinion about euthanasia. Exclusion criteria were being retired or not working as a GP anymore.

\section{Survey}

Since no validated questionnaire to answer our research question was available, and no comparable study had been performed before, a survey was developed (Appendix 2). Based on a literature search, a qualitative interview study[11] and two expert meetings[22], a concept survey was composed. Expert validity of the survey was achieved through pilot testing by six GPs, an ethicist, a journalist, a geriatrician and an elderly psychiatrist, and adapted where necessary.

The survey took 15 minutes to complete. Response options included 'yes', 'no' or 'other' as multiple choice options, with free text room available when participants selected 'other'.

The survey started with questions characterizing personal and clinical practice context. Next, questions on AED and euthanasia requests from PWD followed which have been published elsewhere.[12] Here, we focus on PWADs. We asked for problems with judging whether a PWAD has unbearable suffering with no prospective on improvement, by:

1. A 5 point Likert scale (totally disagree-totally agree) on having problems with judging the specific criterion of unbearable suffering in a competent and in an incompetent patient.

2. Based on a case vignette (BOX 2), the respondents were asked on their judgement whether or not the GP acted correctly. Next some questions were asked on:

a. Can an AED replace an oral request if communication with the patient is not possible anymore (a PWAD)?

b. Can the family initiate a euthanasia procedure and represent the interests of such a PWD?

c. Is it allowed that a PWAD is sedated before euthanasia is performed?

In an open text box, the GPs could explain their answers.

\section{BOX 2 Case Vignette}

Mr. Smit is 70 years old and is indisputably diagnosed with dementia by a geriatrician. He does not recognize his wife and children anymore, refuses to eat, and increasingly isolates himself. Discussing his treatment is not possible anymore. Ten months ago, still being competent, he composed an advance euthanasia directive (AED), in which he declared that he would opt for euthanasia when suffering from dementia. His family is now asking for performing this, given the patient's AED and his unbearable suffering with no prospect of improvement. The general practitioner considers the patient incompetent, can imagine that the patient is unbearably suffering and is convinced that the patient's AED can replace an oral request. The consulted SCEN physician ${ }^{1}$ and elderly care physician confirmed this and approved euthanasia. A sedative was orally administered to prevent possible unpredictable behavior, agitation and startle reactions at which the patient might walk away, after which the GP performed the euthanasia. After having received the written report of the euthanasia procedure from the GP, the regional review committee invites him to give an explanation of his actions.

${ }^{1}$ SCEN; support and consultation on euthanasia in the Netherlands. SCEN physicians are available for support, information and formal consultation around euthanasia

\section{Procedure}

A code list was generated for the unique codes of the surveys and names of the GPs. The survey, for each GP with a unique code, an information letter and a self-addressed return envelope were sent in January 2019 to the GPs by regular mail. Non-responders received a reminder three weeks later. Study flow diagram is shown in figure 1 (appendix 1)

Participation in this study was voluntary and data were processed anonymously.

Participants were not subject to treatment, nor were they required to behave in a particular way. Therefore, the Medical Review Ethics Committee region Arnhem-Nijmegen concluded that this study was not subject to the Medical Research Involving Human Subjects Act (case number 2018-5003). In accordance with the Dutch law, Informed consent was not obtained as data processing was anonymous. Data of the completed surveys were entered in Castor, a valid database, and after closure of the database transported to SPSS. 


\section{Statistical analysis}

All data were analyzed using SPSS software version 25. Frequencies with percentages and means with standard deviations (SDs) were used as descriptive variables.

\section{Results}

\section{Recruitment}

Of the 894 included GPs, 423 (47.3\%) completed the survey. The study flow diagram, describing the procedure and response rate initially and after a reminder is shown in the appendix.

\section{Experienced difficulties judging the due criteria in an incompetent PWD}

Of the responding GPs, 348 (82.4\%) (totally) agreed that it is difficult to judge the due care criterion 'unbearable suffering with no future improvement' of an incompetent person with dementia (PWAD). When it concerns a competent PWD who considers his perspective of future suffering as unbearable, 247 GPs $(58.6 \%)$ (totally) disagreed that in such a case the due care criteria are met.

\section{Case vignette}

On the question if the GP in the case vignette acted correctly, 178 (42.2\%) answered with 'yes' and 210 (49.8\%) with 'no' (Table 1). Seventy-six GPs (18\%) agreed that an AED can replace an oral request if communication with the concerned patient has become impossible, 178 did not agree (42.2 \%) and 158 (37.4\%) answered 'maybe'.

When stating that the family can initiate the start of a euthanasia procedure representing the interests of the concerned patient (in case this patient is not able anymore to confirm such a previously documented wish), 95 (22.5\%) GPs agreed, while 209 (49.5\%) disagreed, and 110 (26.1) said 'maybe'. GPs added in the open text box explanations like: 'this is only an option if I know the family and patient well'; 'if the patient has authorized this family member earlier when he or she was still mentally capable', or 'if the family participated in earlier conversations about euthanasia and if there is no pressure from relatives or conflict of interests'.

Administration of sedative medication prior the euthanasia performance was agreed by 181 GPs (42.9\%) and disagreed by 126 (29.9\%) GPs, while 89 GPs (21.1\%) found this only acceptable if (open text box arguments) the patient is restless and if it was discussed and documented in the AED.

\section{Table 1 Case Vignette and personal view}

\begin{tabular}{|c|c|c|c|c|c|}
\hline & & $\begin{array}{l}\text { number of GPs that responded } \\
\text { to the question }\end{array}$ & $\begin{array}{l}\text { Yes } \\
\text { n (\%) }\end{array}$ & $\begin{array}{l}\text { No } \\
\mathrm{n}(\%)\end{array}$ & $\begin{array}{l}\text { Maybe } \\
\text { N (\%) }\end{array}$ \\
\hline $25 a$ & Do you judge the way of acting of this GP as correct? & 388 & $\begin{array}{l}178 \\
(42.2)\end{array}$ & $\begin{array}{l}210 \\
(49.8)\end{array}$ & - \\
\hline $25 b$ & $\begin{array}{l}\text { An AED can replace an oral request if communication with the concerned } \\
\text { patient is impossible. }\end{array}$ & 412 & $\begin{array}{l}76 \\
(18.0)\end{array}$ & $\begin{array}{l}178 \\
(42.2)\end{array}$ & $\begin{array}{l}158 \\
(37.4)\end{array}$ \\
\hline $25 c$ & $\begin{array}{l}\text { The family can initiate the start of a euthanasia procedure representing the } \\
\text { interests of the concerned patient. }\end{array}$ & 414 & $95(22.5)$ & $\begin{array}{l}209 \\
(49.5)\end{array}$ & $\begin{array}{l}110 \\
(26.1)\end{array}$ \\
\hline $25 d$ & $\begin{array}{l}\text { A sedative medicine prior performing euthanasia to the concerned patient } \\
\text { is allowed. }\end{array}$ & 396 & $\begin{array}{l}181 \\
(42.9)\end{array}$ & $\begin{array}{l}126 \\
(29.9)\end{array}$ & $\begin{array}{l}89 \\
(21.1)\end{array}$ \\
\hline
\end{tabular}

\section{Discussion}

What are the views of Dutch GPs on the obligatory euthanasia criterion of unbearable suffering in PWADs, and on a case vignette about a euthanasia request regarding such a patient with an AED?

We found that the vast majority of Dutch GPs experienced difficulties to adequately judge the for euthanasia obligatory criterion of unbearable suffering with no prospective improvement in a PWAD. After having read a case vignette, one out of five GPs agreed that an AED can replace an oral request in PWADs and that the family can initiate the euthanasia procedure. Two out of five GPs considered sedation prior to euthanasia in this patient group allowed.

Interestingly, the most recent Dutch guideline on performance of euthanasia, which appeared in 2020, after this study was carried out, does not object anymore to sedation (called "pre-medication") if the doctor considers this as appropriate.

In our fictive case vignette, the several elements of the first legal case where the physician was accused of murder, were integrated. At the moment the GPs completed the survey, this case was well-known by all Dutch physicians, as a lot of media attention was given to it. However, at that moment a judicial decision was not yet made. Apparently, this actual case had not largely influenced the GPs' beliefs, as our findings confirmed those from a Dutch interview study from 2015 in which many physicians considered euthanasia in PWAD problematic, both legally and personally.[16] In that interview study, physicians 
were reluctant to forgo adequate verbal communication with the patient, because they wished to verify the voluntariness of a patient's request, and the unbearableness of the actual suffering, and thus consider an AED of limited value in PWAD.

The Dutch law does not give restrictions towards euthanasia in PWAD if it is performed according to the obligatory due care criteria. Recently, the supreme court in The Hague gave clearance and no punishment in the case on which our case vignette was inspired.[19] The argumentation of the Court is mainly based on the concept of 'precedent autonomy' and 'continuity of person', whereby the self-determination to be respected was made at the time the person was still competent. This argumentation is in line with the views of the powerful philosopher of law Ronald Dworkin. Dworkin emphasizes that critical interests -as coded in the AED- should take precedence over experiential interests (from flimsy games to poetry) as expressed by or observed from the patient.[23] According to legal philosopher Rozemond this shows an overestimation of rational faculties of the human mind.[24] Rozemond doubts whether the previous competent self legally can prevail over the present, more or less incompetent self, commonly known as the "then-self-versus now-self" problem. In his reasoning it is a misconception that a loss of memory in dementia necessarily results in a diminished sense of self.[25] A more balanced perspective is suggested in which we factor in both the previously expressed wishes (respecting autonomy) and the current reality (respecting beneficence).[26]As an AED now legally can replace an actual, oral euthanasia confirmation, a PWAD may not have the opportunity anymore to decide on his euthanasia request. Due to the progressive cognitive impairment, emotional - and/or behavioral problems in PWAD, carefully discussing and updating the person's wishes is extremely import. Specifically because consistency in choice and regular conformation of consistency is legally mandatory. An earlier study also showed that many GPs would like to have training to increase their knowledge around AEDs.[11] Up to now, the Royal Dutch Medical Association (KNMG) guideline for physicians gives no requirements for an AED, but is currently developing a new guideline.[27] Consequently, at the moment it is uncertain whether an AED should be considered and thus made as a personal, conversational document, or that it should be a legal notarized pre-printed document, standardized according to the jurisprudence of the supreme court.

We recommend that GPs take advantage of the opportunity when a PWD wants to discuss an AED, to also embark on the overarching advance care planning By using the opportunity to provide realistic information about the dementia trajectory and its consequences, unrealistic fear for future suffering and loss of control may be relieved.[28-30]

The recent concerns of the United Nations- Human rights committee towards the Dutch euthanasia practice can be regarded as an opportunity to elaborate on the experiences of burden and the ethical dilemmas which GPs in the Netherlands are facing.[31] GPs for example could be supported by having opportunities for early ethical review. In line with this, an ethicist and former member of one of the regional euthanasia review committees recently publicly stated that in complex cases, like euthanasia in PWADs is, ethical and moral reflection is largely lacking.[32] She called for a "more proactive review" that is "being broader in scope" for complex cases using a multidisciplinary approach. [33] This implies that there is also a need for a proactive, broader, multidisciplinary decisionmaking process for complex euthanasia requests of PWADs, for instance supported by moral case deliberation (MCD). A recent study showed that addressing harm in MCD aids healthcare professionals in the task they are facing.[34] Giving GPs better access towards MCD would be a sensible policy as it may counteract polarization within the profession and society. In our earlier study we also argued for creating awareness of the possibility to consult a spiritual care provider.[12,35] These suggestions to introduce ethical review ex ante medical decisions on request for termination of life should be further explored, in order to address GPs' personal moral considerations and dealing with social pressure. Better support for physicians in an early phase may be beneficial in all countries dealing with the legalization of euthanasia.

\section{Strengths and limitations}

This quantitative survey is unique in focusing on Dutch GPs' views on euthanasia requests for PWAD. The Dutch jurisdiction on euthanasia and PWAD is interestingly unique, but limited to Dutch territory. The questions raised ethically reach much further. We had a high response rate from all regions of the Netherlands. The relatively high response rate emphasizes GPs' high involvement in this topic, as other surveys among Dutch GPs mostly had much lower response rates (around 30\%).[36-38] The respondents are representative for the Dutch GP practice, as checked for age, gender and region. ${ }^{36}$

A limitation is that the survey could not completely use a validated questionnaire, and only addressed Dutch GPs. However, the basic questionnaire relied on two previous studies and a literature review, and was adapted after having received feedback from six experts.

\section{Conclusion}

In our exploration of the views of general practitioners confronted with an advance euthanasia request from a person with advanced dementia, the vast majority of the responding GPs experienced difficulties judging the obligatory care criteria of the patients' unbearable suffering with no prospective improvement adequately. Despite the fact that euthanasia on the basis of a previous AED is now possible by law for PWAD in the Netherlands, only a minority of GPs supports this. Therefore it can be emphasized that research and development of moral and ethical support throughout the decision making process is needed.

\section{List Of Abbreviations}

AED: advance euthanasia directive

GP: $\quad$ General Practitioner

KNMG: Royal Dutch Medical Association

MCD: Moral Case Deliberation 
PW(A)D:

Person with (Advanced) Dementia

PWDs:

Persons with Dementia

SCEN:

Support and Consultation on Euthanasia in the Netherlands

\section{Declarations}

Ethics approval and consent to participate; Participants were not subject to treatment, nor were they required to behave in a particular way. Participants (General Practitioners) could feel free to participate in the study and give their informed consent. Therefore, the Medical Review Ethics Committee region Arnhem-Nijmegen concluded that this study was not subject to the Medical Research Involving Human Subjects Act (case number 2018-5003). In accordance with the Dutch law, Informed consent was not obtained as data processing was anonymous.

Consent for publication; given by all recipient and authors

Availability of data and materials ; The datasets used and/or analysed during the current study are available from the corresponding author on reasonable request.

\section{Competing interest; none}

Funding; none

Authors' contributions; Study design authors number 1,2 and 5. Data analyse authors number 1,2 and 5. Manuscript written by author 1. All authors reviewed the manuscript

Acknowledgements; not applicable

\section{References}

1. Clark, D., Between hope and acceptance: the medicalisation of dying. BMJ, 2002. 324(7342): p. 905-7.

2. Munday, T. and P. Poon, Geriatricians' attitudes towards voluntary assisted dying: A survey of Australian and New Zealand Society for Geriatric Medicine members. Australas J Ageing, 2020. 39(1): p. e40-e48.

3. Wet toetsing levensbeëindiging op verzoek en hulp bij zelfdoding (Law evaluation of life termination upon request and assisted suicide). 2018 [cited 2020 8 May]; Available from: https://wetten.overheid.nl/BWBR0012410/2018-08-01.

4. RTE. Year reports 2010-2018 of the Regional Evaluation Commissions Euthanasia (RTE). 2018 [cited 20208 May]; Available from: https://www.euthanasiecommissie.nl/de-toetsingscommissies/jaarverslagen.

5. KNMG. Euthanasie in cijfers (Euthanasia in figures). [Infographic] 2019 [cited 20208 May]; Available from: https://www.knmg.nl/adviesrichtlijnen/dossiers/euthanasie.htm.

6. Landeweer, M. Radeloze Joop (81): Soms loopt de urine langs haar enkels (Distraughted Joop: Sometimes her urine drops down her ankles). Algemeen Dagblad (Dutch newspaper) 2016; Available from: https://www.ad.nl/gezond/radeloze-joop-81-soms-loopt-urine-langs-haar-enkels af8145d5/.

7. Grooters, L. Drie inzichten uit de Leeuwenhoektour (Three insights from 'the Leeuwenhoek tour'). 2018 [cited 20208 May]; Available from: https://www.human.nl/in-de-leeuwenhoek/lees/inzichten-tour.html

8. Working together to tackle dementia. 2017 [cited 20208 May]; Available from: https://www.government.nl/latest/news/2017/05/16/working-togetherinternationally-to-tackle-dementia

9. Nederland, A. Factsheets cijfers en feiten over dementie. (Fact sheets dementia figures and facts). 2019 [cited 2021 March 8]; Available from: https://www.alzheimer-nederland.nl/factsheet-cijfers-en-feiten-over-dementie.

10. Van Twillert, M. Meer mensen hebben schriftelijke wilsverklaring (A growing number of people have a written advance directive). Medisch Contact 2018 [cited 20208 May]; Available from: https://www.medischcontact.nl/nieuws/laatste-nieuws/artikel/meer-mensen-hebben-schriftelijke-wilsverklaring.htm.

11. Schuurmans, J., et al., Euthanasia requests in dementia cases; what are experiences and needs of Dutch physicians? A qualitative interview study. BMC Med Ethics, 2019. 20(1): p. 66.

12. Schuurmans, J., et al., Dutch GPs' experience of burden by euthanasia requests from people with dementia: a quantitative survey. BJGP Open, 2021. 5(1).

13. Schuurmans, J., et al., Supporting general practitioners around euthanasia requests from people with dementia: nominal group meetings. BJGP, 2020.

14. Kouwenhoven, P.S.C., et al., Developments in euthanasia practice in the Netherlands: Balancing professional responsibility and the patient's autonomy. Eur J Gen Pract, 2019. 25(1): p. 44-48.

15. de Nooijer, K., et al., [Written advance euthanasia directives in mentally incompetent patients with dementia: a systematic review of the literature]. Ned Tijdschr Geneeskd, 2017. 161: p. D988.

16. Kouwenhoven, P.S., et al., Opinions about euthanasia and advanced dementia: a qualitative study among Dutch physicians and members of the general public. BMC Med Ethics, 2015. 16: p. 7.

17. KNMG. Handreiking schriftelijk euthanasieverzoek (guideline written advanced euthanasia directive). 2015 [cited 2021 March 8]; Available from: https://www.rijksoverheid.nl/documenten/brochures/2015/12/17/handreiking-schriftelijk-euthanasieverzoek-artsenversie. 
18. Miller, D.G., R. Dresser, and S.Y.H. Kim, Advance euthanasia directives: a controversial case and its ethical implications. J Med Ethics, 2019. 45(2): p. 8489.

19. Asscher, E.C.A. and S. van de Vathorst, First prosecution of a Dutch doctor since the Euthanasia Act of 2002: what does the verdict mean? J Med Ethics, 2019.

20. Telegraph, T. Dutch euthanasia doctor cleared over death of dementia patient 2019 [cited 2019 October 31]; Available from: https://www.telegraph.co.uk/news/2019/09/11/dutch-euthanasia-doctor-cleared-death-dementia-patient/.

21. Annual Report 2017 Dementia Cases in the Netherlands. 2018 [cited 2019 August 29]; Available from: https://english.euthanasiecommissie.nl/thecommittees/documents/publications/annual-reports/2002/annual-reports/annual-reports.

22. Schuurmans, J., et al., Supporting GPs around euthanasia requests from people with dementia: a qualitative analysis of Dutch nominal group meetings. Br J Gen Pract, 2020. 70(700): p. e833-e842.

23. Dworkin, R.H., Life's dominion. An argument about abortion, euthanasia, and individual freedom. 1993, New York: Knopf.

24. Rozemond, K., De rampzalige invloed van Ronald Dworkin op het Nederlandse euthanasierecht. Netherlands Journal of Legal Philosophy, 2020.1.

25. Strikwerda-Brown, C., et al., "All is not lost"-Rethinking the nature of memory and the self in dementia. Ageing Res Rev, $2019.54:$ p. 100932.

26. Gillick, M.R., Doing the right thing: a geriatrician's perspective on medical care for the person with advanced dementia. J Law Med Ethics, 2012. 40(1): $\mathrm{p}$. 51-6.

27. Association), K.R.D.M. KNMG-project euthanasie bij dementie (KNMG project euthanasia for persons with dementia). 2021; Available from: https://www.knmg.nl/actualiteit-opinie/beleidsprogrammas/passende-zorg-in-de-laatste-levensfase/knmg-project-euthanasie-bij-dementie.htm

28. Petty, S., et al., Emotional distress with dementia: A systematic review using corpus-based analysis and meta-ethnography. Int J Geriatr Psychiatry, 2018. 33(5): p. 679-687.

29. Lloyd-Williams, M., C. Mogan, and K.H. Dening, Identifying palliative care needs in people with dementia. Curr Opin Support Palliat Care, 2017. 11(4): p. 328-333.

30. Dixon, J., M. Karagiannidou, and M. Knapp, The Effectiveness of Advance Care Planning in Improving End-of-Life Outcomes for People With Dementia and Their Carers: A Systematic Review and Critical Discussion. J Pain Symptom Manage, 2018. 55(1): p. $132-150$ e1.

31. United Nations, H.R.C. Concluding observations on the fifth periodic report of the Netherlands 2019 [cited 2021 March 8]; Available from: http://docstore.ohchr.org/SelfServices/FilesHandler.ashx? enc=6QkG1d\%2FPPRiCAqhKb7yhsrU3mlYiFHtCrYPBecWJaXYxW2v02daSC4q\%2BBvHNhI0YLma4m6RVsc0uaEER\%2B1VxiDyrRzWXoZhY7iKNWVkboF4

32. van Baarsen, B., Een schriftelijke wilsverklaring is nog geen euthanasieverzoek. Misverstanden bij de interpretatie van wetsartikel 2 lid 2 WtI (a written advance directive is not a euthanasia request; Misconceptions in the interpretation of Article 2, Clause 2 of the Termination of Life on Request and Assisted Suicide Act, the Netherlands). Nederlands Juristen Blad, 2020. 95 (2): p. 314-321.

33. van Baarsen, B., De toetsing van euthanasie: zorgen om kwaliteit, argumentatie en normontwikkeling. Tijdschrift voor Gezondheidszorg en Ethiek, 2018. 28(3): p. 79-87.

34. Spronk, B., G. Widdershoven, and H. Alma, Addressing harm in moral case deliberation: the views and experiences of facilitators. BMC Med Ethics, 2020. 21(1): p. 10.

35. Health, M.o. Kamerbrief over aanpak geestelijke verzorging (Parliamentary piece about spiritual care). 2018 [cited 20208 May]; Available from: https://www.rijksoverheid.nl/documenten/kamerstukken/2018/10/08/kamerbrief-over-aanpak-geestelijke-verzorging-levensbegeleiding

36. de Torres, J.P., et al., Prognostic evaluation of COPD patients: GOLD 2011 versus BODE and the COPD comorbidity index COTE. Thorax, 2014.

37. Hasselaar, J.G., et al., Dealing with delicate issues in continuous deep sedation. Varying practices among Dutch medical specialists, general practitioners, and nursing home physicians. Arch Intern Med, 2008. 168(5): p. 537-43.

38. Kouwenhoven, P.S., et al., Euthanasia or physician-assisted suicide? A survey from the Netherlands. Eur J Gen Pract, 2014. 20(1): p. 25-31.

\section{Figures}




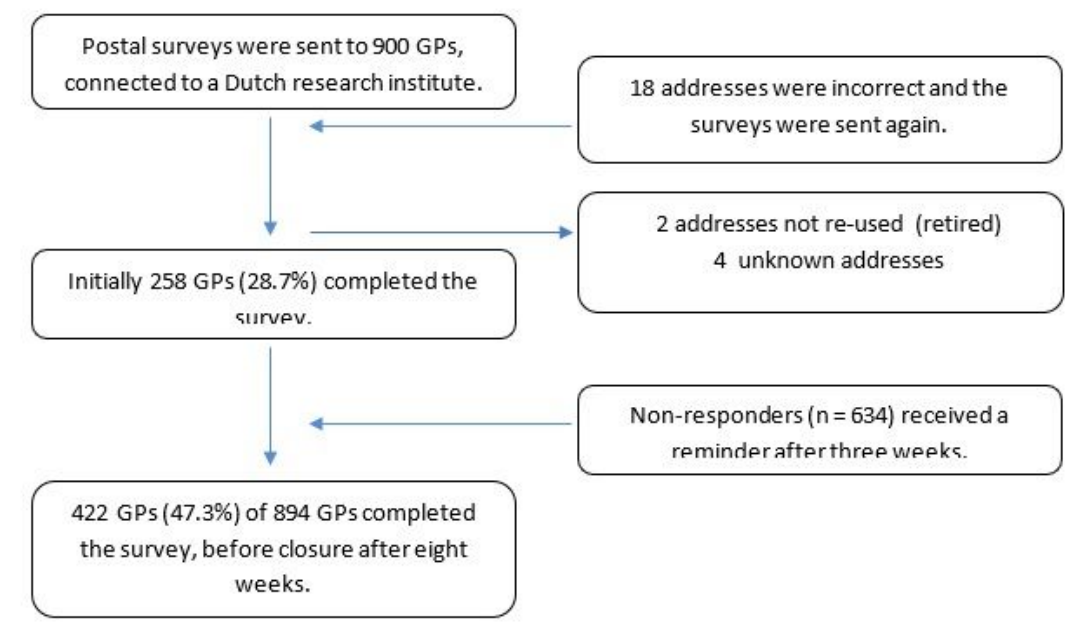

Figure 1

Study flow diagram

\section{Supplementary Files}

This is a list of supplementary files associated with this preprint. Click to download.

- Appendix.pdf 